\title{
User Perception of the Home Robot Price
}

\author{
Joo Hyun Park ${ }^{1}$ and Han Young Ryoo ${ }^{2 *}$ \\ ${ }^{1,2}$ Department of Content Convergence, Ewha Womans University \\ ${ }^{1}$ joohpark@ewha.ac.kr, ${ }^{2}$ hyryoo@ewha.ac.kr
}

\begin{abstract}
The development of the home robot and its service industry is globally getting extra attention. However, the users' perception and reaction of the home robot prices are not systematically studied by the companies. Therefore, this research is conducted to verify the users' perception of the home robot prices. In order to do so, the status of the home robot was investigated first, and then the user target and home robot functions were classified to carry out a survey to check the prices that the users actually estimate. The ratio of the price ranges of the $\$ 300-\$ 500$ and $\$ 500-\$ 700$ was fairly high. The noteworthy aspect was that the working moms tended to evaluate the prices to be expensive; the response ratio of the working moms in the price range of $\$ 700-\$ 900$ and $\$ 900-\$ 1,100$ were higher than the other targets. These results should be considered when setting the prices. Especially when releasing an expensive robot, it should be targeted for a specific group or should provide specialized services. This research should be able to assist in computing the selling price of the home robots and expedite the consumption as well as in designing and developing the home robots that the users can actually purchase.
\end{abstract}

Keywords: Home Robot, Home Robot Price, User Perception, Home Robot's Function

\section{Introduction}

As the home robot is getting more attention lately, the development competition by the major internal and external companies are becoming fierce. At the CES(Customer Electronics Show) held in January 2017, the robot made a meteoric rise as the home hub and the global companies such as Apple, Amazon, Google, and Samsung, etc., introduced various types of home robots that can control all kinds of home appliances and provide emotional services [1,2].

The companies have been trying to dominate the home robot industry by accelerating the development and release of various kinds of home robots. Also, the world main countries are practicing various promoting policies to lead the robot industry[3]. Especially, Japan is supporting a huge investment and fostering policies. Softbank, with all these support from the government, released a human type robot Pepper in 2014 and sold over a ten thousand units. Pepper was promoted as a human friendly robot which can communicate with human beings and even start a conversation. However, with the selling price of approximately $\$ 1,800$, Pepper was mainly purchased by early adaptors or other companies leaving a limit to spread of robots. On the other hand, Jibo, whom press media and the robot industry are paying close attention, is in the spotlight as the leader of home robot. The official release is postponed but the users are getting more and more interested because it is to be sold only for $\$ 499$. Other than Jibo, a variety of home robots with low and high prices, and different prices for different functions, size, and purposes are being released or to be released.

Received (November 26, 2018), Review Result (January 26, 2018), Accepted (February 1, 2018)

* Corresponding Author 
The prices that the users perceive form the foundation of the understanding of the attitude and actions that the users take[4]. However, there usually is a difference between the prices that the users are willing to pay for the robots and the prices that the companies set as selling price. Nevertheless, the robot companies do not have systematical studies on the user perception or reaction of the home robot prices. Thus, this research was conducted for the purpose of the user perception of the home robot prices.

This research was conducted as follows. First, the status of the robots that are already released or to be released was investigated to examine the trends and prices of the home robots. Secondly, the user target was classified considering the right user for the home robots and the functions were divided into the basic ones and additional ones through the status of the home robots. This was due to inquire the differences of the price perception according to the target and functions. Thirdly, a survey was conducted to check the prices that each target estimates for the basic and additional functions. Then the participants were asked to write their reasons why they chose the specific prices. Lastly, through the data analysis from the survey, the directions of the home robot prices were suggested.

\section{Current Status of the Home Robot}

Owing to the rapid technical development of Artificial Intelligence(AI), Internet of Things(IoT), Sensor, and Cloud, the robots with different intelligence appear. Especially the home robots are expected to play a pivotal role in the smart home hub[5]. They can be a conversation partner, a sympathetic object, and a house chore or daily life helper. Plus, it has an important meaning that they can provide entertainment features and guard the home by detecting fire, noises, dangerous factors which all enrich human life[6][7].

In this research, based on the study of the home robot status[8], the trends and prices of the home robots are investigated and the functions are organized. The results of the home robot status were used to have a general understanding of the home robot and used in the questionnaire. The investigated home robot examples are 13 robots altogether and the productions, name, size, functions and services, official release, price and image are organized as in Table 1.

Table 1. Home Robot Examples

\begin{tabular}{|c|c|c|c|c|c|c|}
\hline Production & Name & Size & Function and Service & $\begin{array}{l}\text { Official } \\
\text { Release }\end{array}$ & Price & Image \\
\hline $\begin{array}{l}\text { Aldebaran } \\
\text { Robotics }\end{array}$ & Nao & $\begin{array}{l}58 \mathrm{~cm} \\
5 \mathrm{~kg}\end{array}$ & $\begin{array}{l}\text {-Produced for educational } \\
\text { Purposes } \\
\text {-Controllable through personal } \\
\text { programming } \\
\text {-Capable of interactive } \\
\text { conversation by seeing, listening, } \\
\text { feeling } \\
\text {-Capable of sensing obstacles }\end{array}$ & $\begin{array}{l}\text {-Released in } \\
2017\end{array}$ & $\$ 7,990(\mathrm{Nao}$ V5) & \\
\hline Asus & Zenbo & $\begin{array}{l}37 \mathrm{x} \\
37 \mathrm{x} \\
62 \mathrm{~cm} \\
10 \mathrm{~kg}\end{array}$ & $\begin{array}{l}\text {-Can connect to the home IoT and } \\
\text { appliances to control } \\
\text {-Media(music, movie, photo, etc.) } \\
\text { play, schedule alert } \\
\text {-Can provide screen and } \\
\text { movements as reading a children's } \\
\text { story to visualize it }\end{array}$ & $\begin{array}{l}\text {-Released in } \\
\text { January } 2017 \\
\text { from Taiwan } \\
\text {-To be released } \\
\text { in the late } 2017 \\
\text { from the US }\end{array}$ & $\begin{array}{l}\$ 620(32 \mathrm{G}) \\
\$ 780(128 \mathrm{G})\end{array}$ & \\
\hline
\end{tabular}




\begin{tabular}{|c|c|c|c|c|c|c|}
\hline $\begin{array}{ll}\text { Blue } & \text { Frog } \\
\text { Robotics } & \end{array}$ & Buddy & $\begin{array}{l}35 \mathrm{x} \\
35 \mathrm{x} \\
56 \mathrm{~cm} \\
5 \mathrm{~kg}\end{array}$ & $\begin{array}{l}\text {-Can monitor the house as a herb } \\
\text { by connecting to the other home } \\
\text { appliances through a network } \\
\text {-A family robot which can also act } \\
\text { as a personal secretary and allows } \\
\text { video calls } \\
\text {-Provides living convenience by } \\
\text { providing recipe, playing music, } \\
\text { alarming, answering phone calls } \\
\text {-Can be a playmate to play games } \\
\text { or to educate }\end{array}$ & $\begin{array}{l}\text {-To be released } \\
\text { in the late } 2016\end{array}$ & $\$ 699$ & 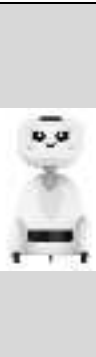 \\
\hline Emotech & Olly & $\begin{array}{l}\text { Approx. } \\
40 \mathrm{~cm}\end{array}$ & $\begin{array}{l}\text {-Loaded with deep learning } \\
\text { techniques to interchange } \\
\text { emotional feelings } \\
\text {-Provides services through voice } \\
\text { recognition } \\
\text {-Can check weather and news or } \\
\text { play music }\end{array}$ & $\begin{array}{l}\text {-To be released } \\
\text { in December } \\
2017 \\
\text {-Publically } \\
\text { announced in } \\
\text { January } 2017\end{array}$ & $\$ 700$ & \\
\hline $\begin{array}{l}\text { Intuition } \\
\text { Robotics }\end{array}$ & Elli.Q & $\begin{array}{l}\text { Approx. } \\
30 \mathrm{~cm}\end{array}$ & $\begin{array}{l}\text {-Helps the loneliness of the old } \\
\text { and solves their lack of social } \\
\text { activity, facilitate to contact with } \\
\text { family and friends } \\
\text {-Can act as a personal secretary by } \\
\text { reminding to take medicine or to } \\
\text { attend a meeting } \\
\text {-Helps leisure life by connecting to } \\
\text { the digital contents, noon, skype }\end{array}$ & $\begin{array}{l}\text {-To be executed a } \\
\text { test operation in } \\
\text { February } 2017 \text { in } \\
\text { San Francisco }\end{array}$ & $\begin{array}{l}\text { To Be } \\
\text { Determined }\end{array}$ & \\
\hline Jibo & Jibo & $\begin{array}{l}28 \mathrm{~cm} \\
2.7 \mathrm{~kg}\end{array}$ & $\begin{array}{l}\text {-Social robot for home use } \\
\text {-Can send messages, take photos, } \\
\text { remind, story-telling, video calls } \\
\text {-Can act as a messenger by } \\
\text { connecting to the OS of the iphone } \\
\text { or android } \\
\text {-Can be connected to the home } \\
\text { appliances to control them }\end{array}$ & $\begin{array}{l}\text {-To be released } \\
\text { in the late } 2017 \\
\text {-Publically } \\
\text { announced in } \\
\text { July } 2014\end{array}$ & $\$ 499$ & \\
\hline LG & Hub Robot & $\begin{array}{l}\text { Approx. } \\
50 \mathrm{~cm}\end{array}$ & $\begin{array}{l}\text {-Can control home appliances by } \\
\text { using the wireless internet } \\
\text {-Can recognize the user's voice } \\
\text { and actions by the mini robots } \\
\text { situated everywhere in the house }\end{array}$ & $\begin{array}{l}\text {-To be } \\
\text { determined to } \\
\text { release } \\
\ddot{Y} \text { Publically } \\
\text { announced in } \\
\text { January } 2017\end{array}$ & $\begin{array}{l}\text { To Be } \\
\text { Determined }\end{array}$ & \\
\hline $\begin{array}{l}\text { Mayfield } \\
\text { Robotics }\end{array}$ & Kuri & $\begin{array}{l}50.8 \mathrm{~cm} \\
6.4 \mathrm{~kg}\end{array}$ & $\begin{array}{l}\text {-Can recognize family members } \\
\text { through face recognition } \\
\text {-Auto-recognition of the home } \\
\text { structure, security management } \\
\text {-Can play with kids by playing } \\
\text { contents(music, etc.), sharing } \\
\text { feelings, story playing }\end{array}$ & $\begin{array}{l}\text {-To be released } \\
\text { in December } \\
2017\end{array}$ & $\$ 699$ & \\
\hline NTT & Sota & $\begin{array}{l}28 x \\
14 \times \\
16 \mathrm{~cm} \\
0.763 \mathrm{~kg}\end{array}$ & $\begin{array}{l}\text {-Communicational robot to support } \\
\text { the elderly life } \\
\text {-Can conduct a natural } \\
\text { conversation as a human } \\
\text {-Can conduct a conversation } \\
\text { between robots and looks at the } \\
\text { people when jumped into the on- } \\
\text { going conversation and continues }\end{array}$ & $\begin{array}{l}\text {-To be released } \\
\text { in } 2017 \\
\text {-Executed test } \\
\text { operations in } \\
\text { banks, nursing } \\
\text { homes in } 2016\end{array}$ & $\$ 800$ & \\
\hline Sharp & Robohon & $\begin{array}{l}19.5 \mathrm{~cm} \\
0.39 \mathrm{~kg}\end{array}$ & $\begin{array}{l}\text {-Has phone call and } \\
\text { communication functions of the } \\
\text { mobile phone } \\
\text {-Dances to the alarm, greetings } \\
\text {-Function as a personal secretary } \\
\text { to call a taxi or find a restaurant, } \\
\text { etc. } \\
\text {-Can watch a movie anywhere by } \\
\text { installing a beam projector }\end{array}$ & $\begin{array}{l}\text {-Released in May } \\
2016\end{array}$ & $¥ 198,000$ & \\
\hline
\end{tabular}




\begin{tabular}{|c|c|c|c|c|c|c|}
\hline Softbank & Pepper & $\begin{array}{l}121 \times \\
42.5 \times \\
48.5 \mathrm{~cm} \\
28 \mathrm{~kg}\end{array}$ & $\begin{array}{l}\text {-Can communicate with a person } \\
\text {-Can start a conversation when the } \\
\text { robot feels necessary } \\
\text {-Can analyze the voice and facial } \\
\text { expressions through motion sensor } \\
\text { to read and study the human's } \\
\text { feelings }\end{array}$ & $\begin{array}{l}\text {-Released in } \\
\text { February } 2015\end{array}$ & $¥ 198,000$ & is \\
\hline $\begin{array}{l}\text { Ubtech } \\
\text { Robotics }\end{array}$ & Alpha 2 & $\begin{array}{l}43.8 \mathrm{x} \\
21.8 \mathrm{x} \\
12.2 \mathrm{~cm}\end{array}$ & $\begin{array}{l}\text {-Functions for children like multi- } \\
\text { media, education, games, and } \\
\text { plays } \\
\text {-Can manage schedule, provide } \\
\text { weather or traffic conditions start a } \\
\text { conversation, show yoga poses, } \\
\text { etc. } \\
\text {-Can control the lighting or lock in } \\
\text { the house }\end{array}$ & $\begin{array}{l}\text {-Released in } \\
\text { February } 2016\end{array}$ & $\$ 1,300$ & to \\
\hline $\begin{array}{l}\text { Ubtech } \\
\text { Robotics }\end{array}$ & Lynx & $\begin{array}{l}43.8 \mathrm{x} \\
21.8 \mathrm{x} \\
12.2 \mathrm{~cm}\end{array}$ & $\begin{array}{l}\text {-Loaded with the amazon's } \\
\text { artificial intelligence } \\
\text {-Can do video calls, monitor the } \\
\text { area, dance to the music, and } \\
\text { manage schedules } \\
\text {-Loaded with the artificial } \\
\text { intelligence as a humanoid robot }\end{array}$ & $\begin{array}{l}\text {-To be released } \\
\text { in the late } 2017 \\
\text {-Publically } \\
\text { announced in } \\
\text { January } 2017\end{array}$ & $\$ 800-\$ 1,000$ & $\frac{6}{25}$ \\
\hline
\end{tabular}

The functions of the above examined thirteen home robots have been organized below. The types of the functions were divided into the basic and additional ones. The basic functions include the ones that can be commonly found in the released or to be released robots whereas the additional functions refer to the strategically specialized functions featured in the already released robots or to be available in a few years. The contents of each function are organized in the Table 2 .

Table 2. Home Robot's Function

\begin{tabular}{|l|l|l|}
\hline Type & Feature & Detailed function \\
\hline Basic Function & Communication & $\begin{array}{l}\text { To be synchronized with mobile phone } \\
\text { functions(Phone call alarm, Answering phone } \\
\text { calls, Message Alarm, Answering messages, } \\
\text { Video calls) }\end{array}$ \\
\cline { 2 - 3 } & Entertainment & $\begin{array}{l}\text { Photo, Video, Music, Movie, fairy tale contents, } \\
\text { Youtube player }\end{array}$ \\
\cline { 2 - 3 } & Lifestyle & Alarm, Scheduler, Weather \\
\cline { 2 - 3 } & Remote Control & Monitoring through remote controlling \\
\cline { 2 - 3 } & $\begin{array}{l}\text { Emotional } \\
\text { Expression }\end{array}$ & $\begin{array}{l}\text { Emotional expressions through facial } \\
\text { expressions, movements, voices, and sound } \\
\text { effects }\end{array}$ \\
\cline { 2 - 4 } & Voice & $\begin{array}{l}\text { Input(User's Voice): Function execution, Media } \\
\text { play, Information search } \\
\text { Output(Robot's Voice): Providing Information, } \\
\text { Starting a conversation, Answering and talking }\end{array}$ \\
\hline Additional & Pet Care & Taking care of the pets, monitoring \\
\cline { 2 - 3 } & Baby Care & $\begin{array}{l}\text { Taking care of the babies, monitoring } \\
\text { information, functions to communicate with the } \\
\text { family }\end{array}$ \\
\cline { 2 - 3 } & Silver Care & $\begin{array}{l}\text { Home appliance control, House environment } \\
\text { management } \\
\text { Daily supplies, Grocery order }\end{array}$ \\
\cline { 2 - 3 } & $\begin{array}{l}\text { Home } \\
\text { Management } \\
\text { or Gas leakage detection }\end{array}$ \\
\hline Shopping & Security &
\end{tabular}




\section{Survey of the User Perception of the Home Robot Price}

\subsection{Survey Summary}

A survey had been conducted to check the user perception of the home robot price. In order to investigate in depth, the user target has been classified and the home robot functions that were mentioned earlier have been utilized. First, the classification of the user target was to get detailed analysis results of the user perception of the home robot prices. The user target was divided into the single person households, the households with young children, and the households with grown children. Then, according to the gender and occupation, they were subdivided into 8 targets, such as male in single-person households, female in singleperson households, male with young children, working mom with young children, housewife with young children, male with grown children, working mom with grown children, and housewife with grown children. Next, the prices for the basic functions and the additional functions in Table 2 have been investigated respectively and compared to estimate the reasonable prices for the home robots with the basic functions that the users suppose. This was also to see if the prices should increase when the additional functions are added to the basic ones or if there is any other factors that affect the price.

The total number of participants in the survey was 572 which included 84 male and 84 female in single-person household, 59 housewives, 53 working moms, and 96 male in the household with young children, 57 housewives, 54 working moms, 85 male in the household with grown children. The questionnaire was composed of the prices for the basic and additional functions respectively. The additional functions were presented as supplementary features on top of the basic functions. Considering the prices of the released or to be released robots, the quoted prices in the survey were set as $\$ 300-\$ 500, \$ 500-\$ 700, \$ 700-\$ 900, \$ 900-\$ 1,100, \$ 1,100$ $\$ 1,300, \$ 1,300-\$ 1,500$, over $\$ 1,500$, and miscellaneous. Also, all the participants were to answer in writing why they chose the specific prices.

\subsection{Results of the Price for the Basic Functions}

Table 3 and Figure 1 show the price evaluation of the basic functions for each target. The total of 572 participants chose the price range for the home robots as in the following order; $\$ 500-\$ 700(33.04 \%), \$ 300-\$ 500(23.25 \%)$, $\$ 700-\$ 900(14.86 \%)$, $\$ 900-\$ 1,100(11.01 \%), \quad \$ 1,100-\$ 1,300(7.52 \%), \quad \$ 1,300-\$ 1,500(3.50 \%)$, and over $\$ 1,500(4.72 \%)$. To look at each price range closely, the male with young children and the housewives with grown children said that the price range of $\$ 300-\$ 500$ is somewhat inexpensive whereas the working moms with both young children and grown children found it relatively expensive. For the price range of $\$ 500-\$ 700$, the female in the single-person household found it low-priced while the working moms with grown children thought it is high-priced. Most targets found the price range of $\$ 700-\$ 900$ expensive except for the working moms and housewives with young children. For the next price range of $\$ 900-\$ 1,100$, many targets found it expensive except for the working moms with grown children. For the price range of $\$ 1,100$ $\$ 1,300$, most participants found it pricey as well except for the working moms with young children. The last two price ranges of $\$ 1,300-\$ 1,500$ and over $\$ 1,500$, the majority said it is too expensive. 
Table 3. Price Evaluation Results of the Basic Functions for each Target

\begin{tabular}{|c|c|c|c|c|c|c|c|c|c|}
\hline $\begin{array}{l}\text { Prices } \\
\text { (US\$) }\end{array}$ & $\begin{array}{c}\text { Total\% } \\
\text { (number } \\
\text { of people) }\end{array}$ & $\begin{array}{c}\text { Male in } \\
\text { single } \\
\text { person } \\
\text { household }\end{array}$ & $\begin{array}{l}\text { Female in } \\
\text { single } \\
\text { person } \\
\text { household }\end{array}$ & $\begin{array}{l}\text { Male in } \\
\text { household } \\
\text { with } \\
\text { young } \\
\text { children }\end{array}$ & $\begin{array}{l}\text { Housewife } \\
\text { in } \\
\text { household } \\
\text { with } \\
\text { young } \\
\text { children }\end{array}$ & $\begin{array}{c}\text { Working } \\
\text { mom in } \\
\text { household } \\
\text { with } \\
\text { young } \\
\text { children }\end{array}$ & $\begin{array}{c}\text { Male in } \\
\text { household } \\
\text { with } \\
\text { grown } \\
\text { children }\end{array}$ & $\begin{array}{c}\text { Housewife } \\
\text { in } \\
\text { household } \\
\text { with } \\
\text { grown } \\
\text { children }\end{array}$ & $\begin{array}{l}\text { Working } \\
\text { mom in } \\
\text { household } \\
\text { with } \\
\text { grown } \\
\text { children }\end{array}$ \\
\hline & ) & 2 & $23.81(20)$ & ) & 6) & (6) & 15 & 17) & $12.96(7)$ \\
\hline $\begin{array}{r}\$ 51 \\
-\$ 7 \\
\end{array}$ & $33.04(189)$ & $30.95(26)$ & $40.48(34)$ & $5.42(34)$ & $30.51(18)$ & $33.96(18)$ & $34.12(29)$ & 29.82(17) & $24.07(13)$ \\
\hline $\begin{array}{r}\$ 7 \\
-\$ 1 \\
\end{array}$ & ) & $15.48(13)$ & 7 & 1) & $22.03(13)$ & 24.53(13) & 12. & $12.28(7)$ & $14.81(8)$ \\
\hline$\$ 900$ & $.01(03)$ & $.90(10)$ & 7.14 & 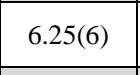 & $78(4)$ & 55 & 17. & $10.53(6)$ & $22.22(12)$ \\
\hline $\begin{array}{l}\$ \\
-\$\end{array}$ & $7.52(43$ & $5(5)$ & 71466 & 21 & $78(4)$ & $13.21(7)$ & $824(7)$ & 700 & $9.26(5)$ \\
\hline $\begin{array}{r}\$ 1,300 \\
-\$ 1,500 \\
\end{array}$ & 3 . & 19(1) & $2.38(2)$ & & $69(1)$ & $66(3)$ & & 5.2 & 3.7 \\
\hline $\begin{array}{c}\text { Over } \\
\$ 1,500 \\
\end{array}$ & $4.72(27)$ & נ) & $3.57(3)$ & $5.21(5)$ & 2) & $1.89(1)$ & ) & $3.51(2)$ & +) \\
\hline $\begin{array}{l}\text { Miscell- } \\
\text { aneous }\end{array}$ & 2 & & & $1.04(1)$ & $1.69(1)$ & & & 1 & \\
\hline Total & $100(572)$ & $100(84)$ & $100(84)$ & $00(96)$ & $100(59)$ & $100(53)$ & $100(85)$ & $100(57)$ & $100(54)$ \\
\hline
\end{tabular}

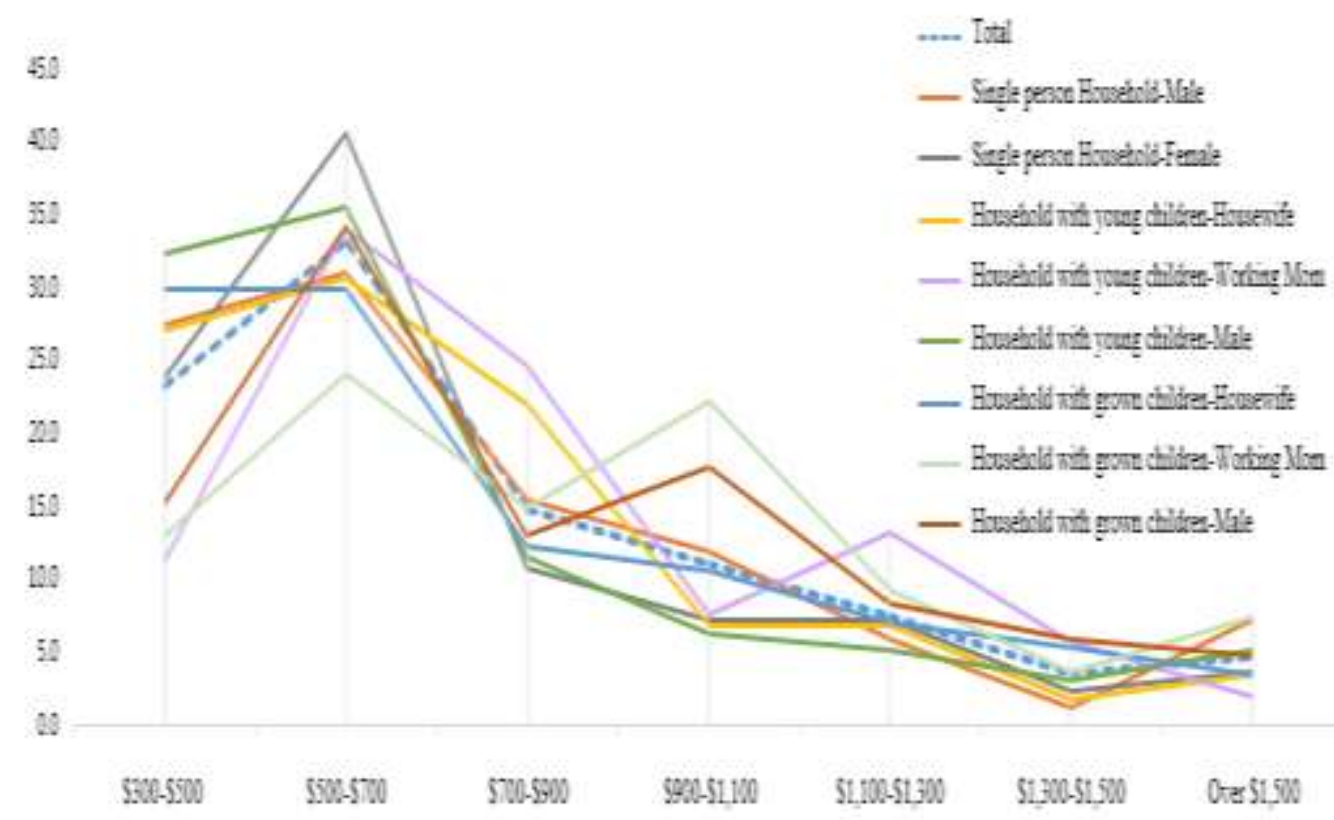

Figure 1. Price Evaluation Results of the Basic Functions for Each Target

The participants were asked to answer why they think the price range that they selected is reasonable for the basic functions. Excluding the opinions that are not directly associated with their choice, the 12 meaningful reasons are as follows; reasonable for the functions, appropriate price range, down-market price, no need to be expensive, a variety of technology and functions, prices compared to the smart phones, prices for similar home appliances, fairly similar to the price of the pets, negative perception, seems to be expensive, no special functions, and personal necessity. Figure 2 illustrate the number of times that each reason was mentioned by eight targets in each price range. 

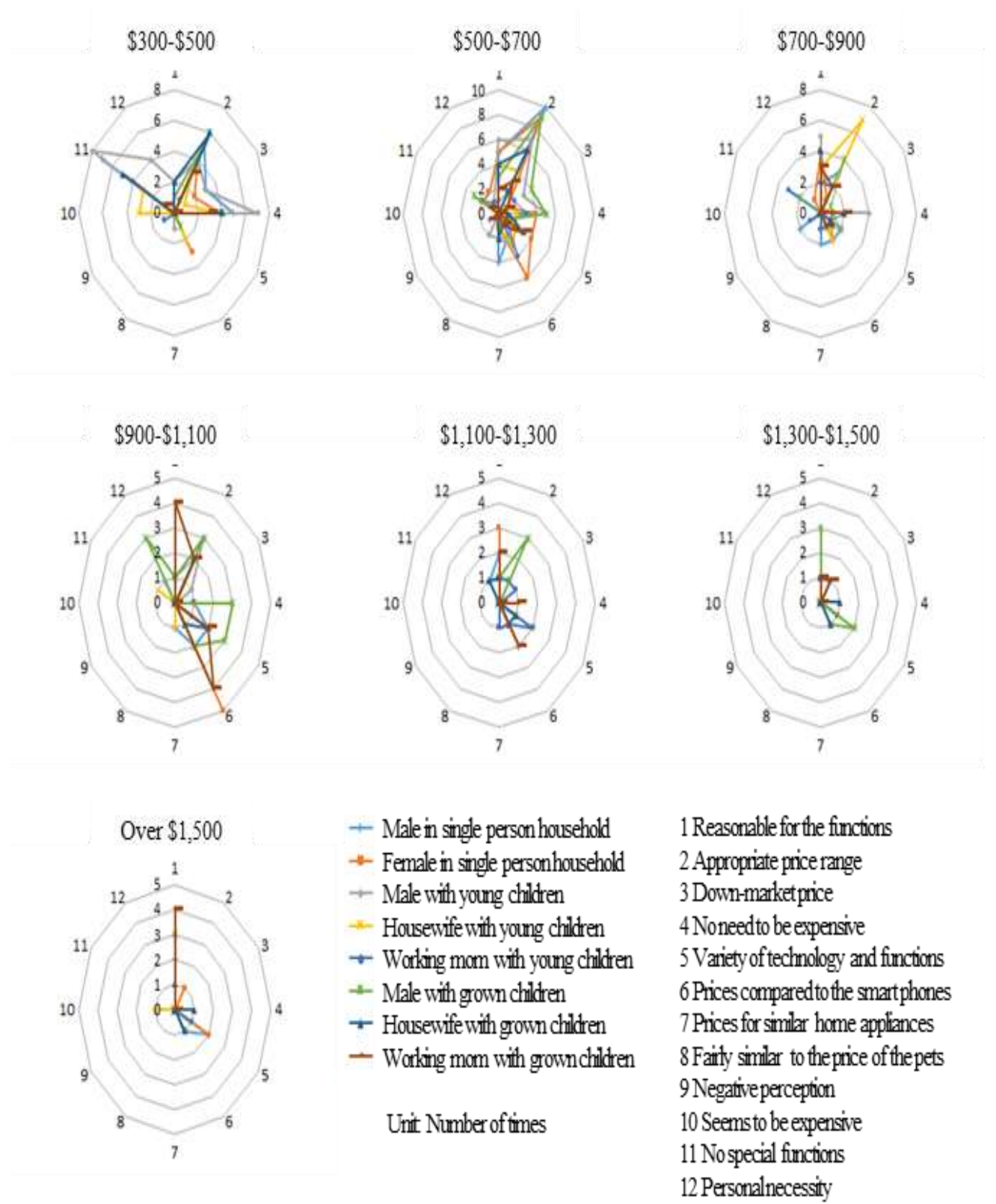

Figure 2. Opinions about the Price for the Basic Functions for Each Target

\subsection{Results of the Price for the Additional Functions}

Table 4 and Figure 3 show the price evaluation of the additional functions for each target. The total of 572 participants selected the price range for the home robots as in the following order; $\$ 500-\$ 700(30.07 \%)$, $\$ 700-\$ 900(16.26 \%)$, $\$ 300$ $\$ 500(16.08 \%), \quad \$ 900-\$ 1,100(13.64 \%), \quad \$ 1,100-\$ 1,300(8.57 \%), \quad \$ 1,300-$ $\$ 1,500(7.17 \%)$, and over $\$ 1,500(6.29 \%)$. To examine each price range in detail, the lowest price range of $\$ 300-\$ 500$ was chosen best by the male in single-person household but the male and the working moms with grown children and the working moms with young children found it relatively expensive. The housewives with grown children said the price range of $\$ 500$ - $\$ 700$ is very reasonable whereas the working moms with grown children found it a little pricey. For the price range of $\$ 700-\$ 900$, most of the targets evaluated with the similar ratio while the female in single-person household evaluated as comparatively high. Also, many participants 
evaluated the price range of $\$ 900-\$ 1,100$ with the similar ratio except for the working moms with young children who evaluated as high. For the next two price ranges of $\$ 1,100-\$ 1,300$ and $\$ 1,300-\$ 1,500$, they were evaluated as fairly low by the majority excluding the working moms with grown children. Lastly, the response rate for the price range of over $\$ 1,500$ was pretty low in the most of the targets.

\section{Table 4. Price Evaluation Results of the Additional Functions for each Target}

\begin{tabular}{|c|c|c|c|c|c|c|c|c|c|}
\hline $\begin{array}{c}\text { Prices } \\
\text { (US\$) }\end{array}$ & $\begin{array}{c}\text { Total\% } \\
\text { (number } \\
\text { of people) }\end{array}$ & $\begin{array}{c}\text { Male in } \\
\text { single } \\
\text { person } \\
\text { household }\end{array}$ & $\begin{array}{c}\text { Female in } \\
\text { single } \\
\text { person } \\
\text { household }\end{array}$ & $\begin{array}{c}\text { Male in } \\
\text { household } \\
\text { with } \\
\text { young } \\
\text { children }\end{array}$ & $\begin{array}{c}\text { Housewife } \\
\text { in } \\
\text { household } \\
\text { with } \\
\text { young } \\
\text { children }\end{array}$ & $\begin{array}{c}\text { Working } \\
\text { mom in } \\
\text { household } \\
\text { with } \\
\text { young } \\
\text { children }\end{array}$ & $\begin{array}{c}\text { Male in } \\
\text { household } \\
\text { with } \\
\text { grown } \\
\text { children }\end{array}$ & $\begin{array}{c}\text { Housewife } \\
\text { in } \\
\text { household } \\
\text { with } \\
\text { grown } \\
\text { children }\end{array}$ & $\begin{array}{c}\text { Working } \\
\text { mom in } \\
\text { household } \\
\text { with } \\
\text { grown } \\
\text { children }\end{array}$ \\
\hline $\begin{array}{c}\$ 300 \\
-\$ 500\end{array}$ & $16.08(92)$ & $26.19(22)$ & $14.29(12)$ & $20.83(20)$ & $16.95(10)$ & $11.32(6)$ & $10.59(9)$ & $12.28(7)$ & $11.11(6)$ \\
\hline $\begin{array}{c}\$ 500 \\
-\$ 700\end{array}$ & $30.07(172)$ & $22.62(19)$ & $34.52(29)$ & $36.46(35)$ & $30.51(18)$ & $22.64(12)$ & $30.59(26)$ & $42.11(24)$ & $16.67(9)$ \\
\hline $\begin{array}{c}\$ 700 \\
-\$ 900\end{array}$ & $16.26(93)$ & $16.67(14)$ & $22.62(19)$ & $14.58(14)$ & $16.95(10)$ & $18.87(10)$ & $15.29(13)$ & $12.28(7)$ & $11.11(6)$ \\
\hline $\begin{array}{c}\$ 900 \\
-\$ 1,100\end{array}$ & $13.64(78)$ & $15.48(13)$ & $5.95(5)$ & $11.46(11)$ & $16.95(10)$ & $22.64(12)$ & $17.65(15)$ & $7.02(4)$ & $14.81(8)$ \\
\hline $\begin{array}{c}\$ 1,100 \\
-\$ 1,300\end{array}$ & $8.57(49)$ & $7.14(6)$ & $7.14(6)$ & $6.25(6)$ & $5.08(3)$ & $7.55(4)$ & $10.59(9)$ & $8.77(5)$ & $18.52(10)$ \\
\hline $\begin{array}{c}\$ 1,300 \\
-\$ 1,500\end{array}$ & $7.17(41)$ & $3.57(3)$ & $4.76(4)$ & $4.17(4)$ & $8.47(5)$ & $9.43(5)$ & $7.06(6)$ & $10.53(6)$ & $14.81(8)$ \\
\hline $\begin{array}{c}\text { Over } \\
\$ 1,500\end{array}$ & $6.29(36)$ & $8.33(7)$ & $7.14(6)$ & $5.21(5)$ & $3.39(2)$ & $5.66(3)$ & $7.06(6)$ & $5.26(3)$ & $7.41(4)$ \\
\hline $\begin{array}{c}\text { Miscell- } \\
\text { aneous }\end{array}$ & $1.92(11)$ & $0(0)$ & $3.57(3)$ & $1.04(1)$ & $1.69(1)$ & $1.89(1)$ & $1.18(1)$ & $1.75(1)$ & $5.56(3)$ \\
\hline Total & $100(572)$ & $100(84)$ & $100(84)$ & $100(96)$ & $100(59)$ & $100(53)$ & $100(85)$ & $100(57)$ & $100(54)$ \\
\hline
\end{tabular}

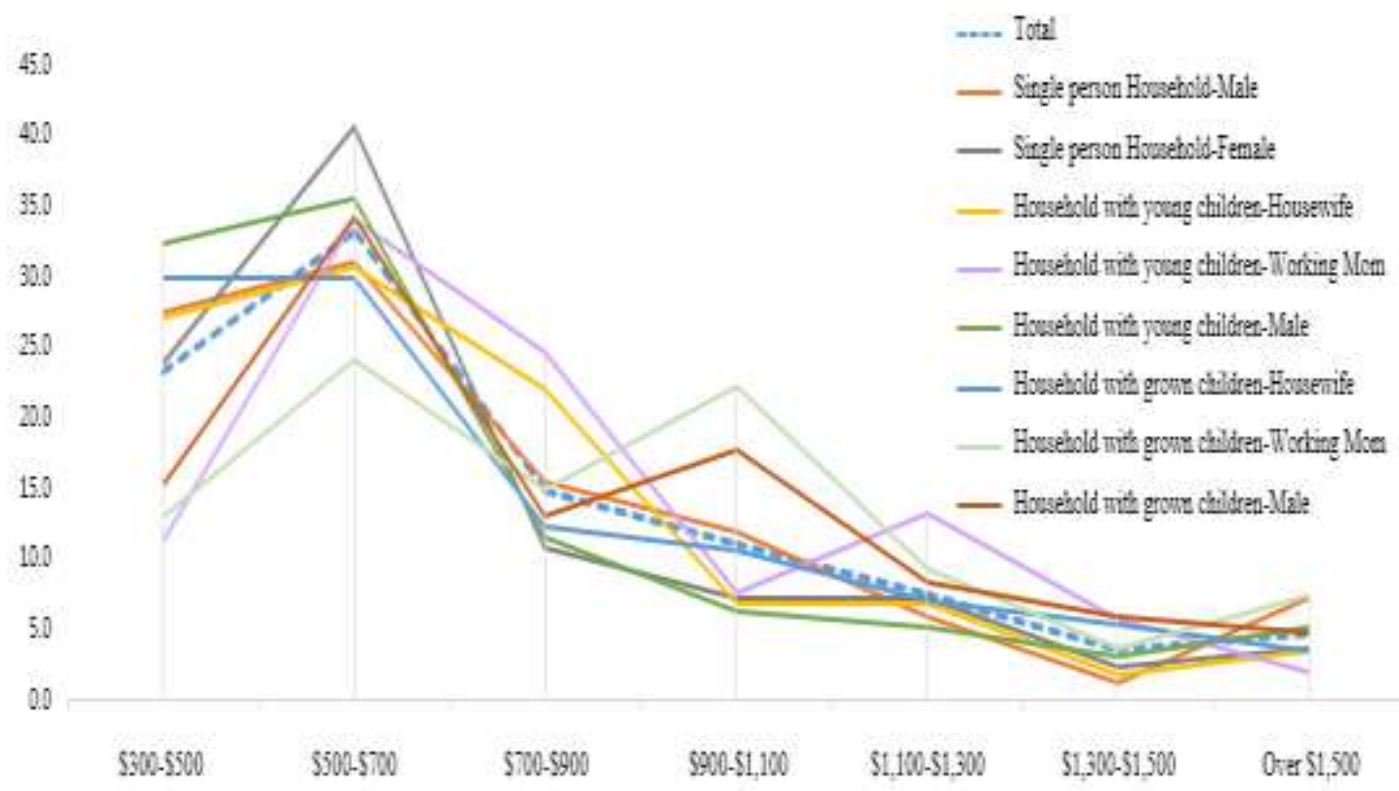

Figure 3. Price Evaluation Results of the Additional Functions for Each Target

The participants were asked to answer their reasons for the selected price ranges for the additional functions. Same as for the responses for the basic functions, there 
were 12 different reasons. Figure 4 illustrates the number of times that each reason was mentioned by eight targets in each price range.
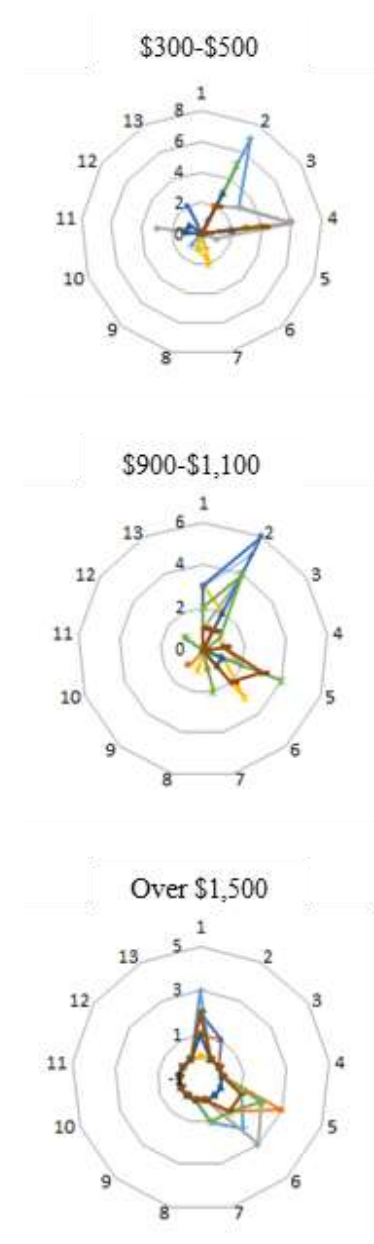
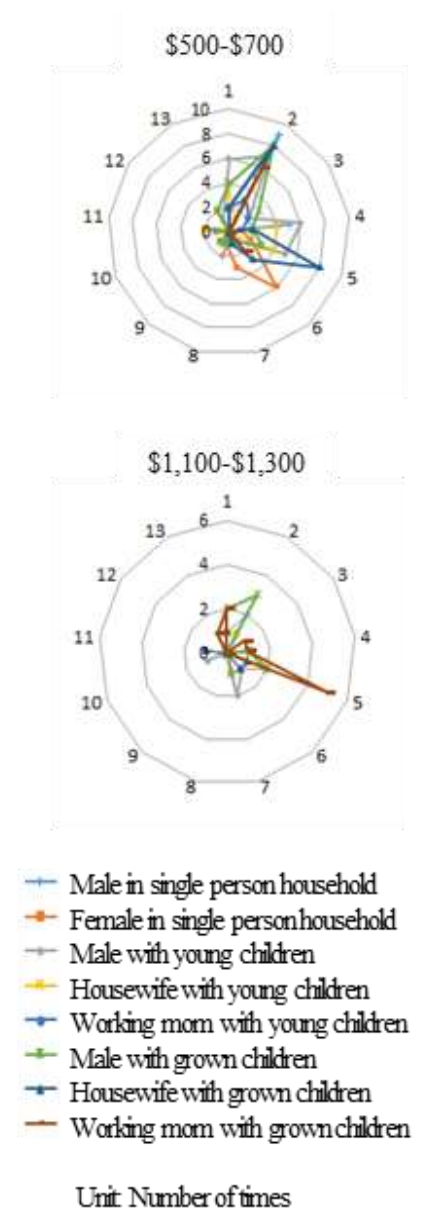

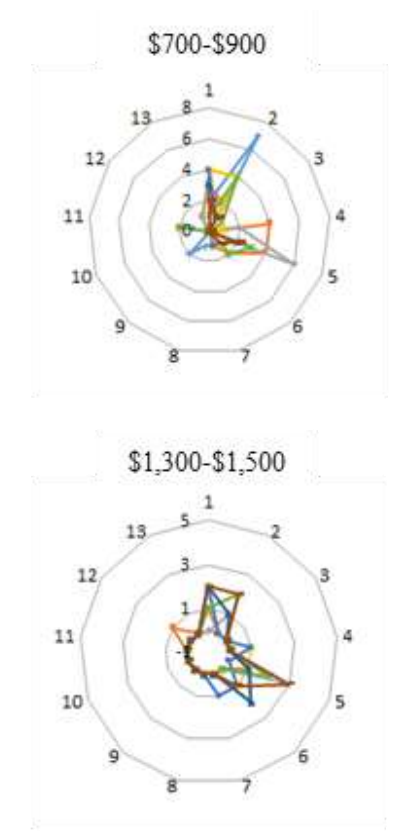

1 Reasonable for the functions

2 Appropriate price range

3 Down-marketprice

4 Noneed to be expensive

5 Variety of technology and functions

6 Prices compared to the smart phones

7 Prices for similar home appliances

8 Failly similar to the price of the pets

9 Negative perception

10 Seems to be expensive

11 No special functions

12 Personalnecessity

Figure 4. Opinions about the Price for the Additional Functions for Each Target

\subsection{Price Comparison between the Basic and Additional Functions}

The price comparisons of the basic functions and additional functions for eight targets are illustrated in Figure 5. Overall, the price range of $\$ 500-\$ 700$ was selected best for both the basic functions and additional functions followed by the price range of $\$ 300-\$ 500$. Especially, the additional functions were evaluated as low in the price range of $\$ 300-\$ 500$, and the price for the additional functions were highly evaluated than the basic functions. The most of the targets also evaluated the price for the additional functions higher than for the basic functions. Meanwhile, the working moms estimated the price of the home robots fairly high. The proportion of the price range of $\$ 700-\$ 900$ and $\$ 900-\$ 1,100$ in the responses from the working moms with grown children was high for the basic functions and the price ranges of $\$ 1,100-\$ 1,300$ and $\$ 1,300-\$ 1,500$ for the additional functions were selected the most by the same target. Also, most of the working moms with young children selected the price range of $\$ 700-\$ 900$ and $\$ 900-\$ 1,100$ compared to the other price ranges. 

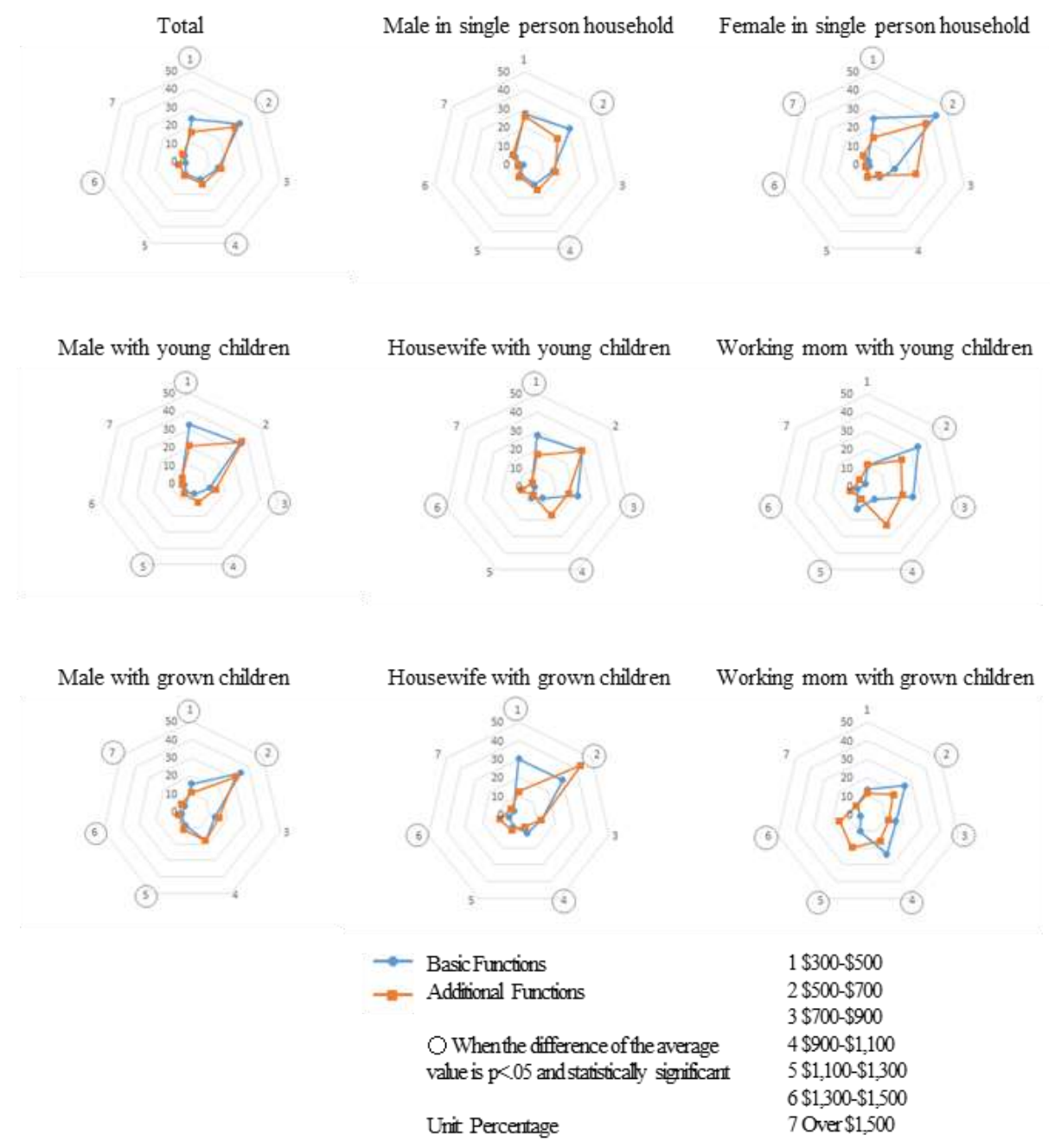

Figure 5. Price Comparisons between Basic and Additional Functions for
Each Target

\section{Conclusion}

This research was conducted to seek the user perception of the home robot price. To do so, the real status of the home robots were investigated first and the user target and the functions were classified for a survey in order to verify the prices that the users estimate. As a result, the ratio of the responses in the price ranges of $\$ 300$ $\$ 500$ and $\$ 500-\$ 700$ for the basic functions out of the total of 572 participants was $56.29 \%$. The ratios of the responses in the price range of $\$ 500-\$ 700, \$ 700-\$ 900$, and $\$ 300-\$ 500$ for the additional functions were $30.07 \%, 16.26 \%$ and $16.08 \%$ respectively. The price range of $\$ 500-\$ 700$ was selected the most while there was no significant difference between the ratios between the other two price ranges. To take a look at the reasons for the responses, most of the participants said that the price ranges of 300-\$500 and $\$ 500-\$ 700$ seem reasonable and there is no need to be expensive for the home robot; many of them also said that there is no special feature in the basic functions. Moreover, the price ranges of $\$ 500-\$ 700, \$ 700-\$ 900$ and $\$ 900-\$ 1,100$ were mostly selected by the participants who compared the price of the smart phones. The noticeable aspect here is that the working moms tend to estimate the home robot prices high. Relatively a lot of the working moms with grown children chose the price ranges of $\$ 700-\$ 900$ and $\$ 900-\$ 1,100$ compared to the other targets and many of the working moms with young children selected the price 
range of $\$ 900-\$ 1,100$. Based on these results, the following directions about the home robot prices are suggested.

Considering the results of the survey, the users seem to expect to have inexpensive home robots. The majority selected the price ranges of $\$ 300-\$ 500$ and $\$ 500-\$ 700$, the lowest price ranges out of all. When selecting the prices for the additional functions, the ratio of the price range of $\$ 700-\$ 900$ was a little high but not high enough to affect the overall results. The participants picked the price ranges of $\$ 300-\$ 500$ and $\$ 500$ - $\$ 700$ mainly due to reasonably prices, no need to be expensive and no special function loaded. Therefore, many users still prefer moderate prices when it comes to purchase a home robot. It is possible that the prices of the robots are evaluated to be low because most of the functions in the robots that are recently released can be also run by the smart phones as well as controlling or monitoring the home appliances by utilizing the IoT. However, the key services that the home robot provide and differentiate them from the other devices are the efficient voice interaction functions and the emotional sympathy. These major services should definitely be well-explained and promoted. Although the importance and the necessity of the social robots or emotional robots are emphasized, it is understood that the users already grasped the fact that the technical development is in the early stage. Therefore, if the companies release a high value home robot, it is inevitable to explain why and how the price was determined or to have a thorough understanding of the users.

The expensive robots should be made for a specific target with specialized services. From the survey results, the working moms are positive and willing to purchase a high-priced robot. Considering the references in regards with the working moms, they have to make supper for the family and run house chores after work and wake up in the morning and get ready for work as well as taking care of the family; they also have unsatisfied feeling of spending more time with their children[9][10][11]. They especially want to monitor their children while at work and need an object that helps housework and take care of the family at home. These difficulties turned into their needs of the home robots and they are inclined to buy one even for a relatively high price. The home robots are perceived as the being that will solve their difficulties as well as allow them to spend valuable time with the family. The companies should, before developing the home robots, work on the in depth research on the users, not only to include the working moms, and determine the specific targets and what kinds of services they want. These strategies will be useful to dominate the home robot market and to lead after all.

The home robot market is still in the beginning phase with limitations of the technical development. Thus, there is only a small quantity of the robots at the moment, the release of the new robots is repeatedly delayed and test operations are on-going. The companies should keep making continuous development and investments on a long-term strategy for the popularization of the home robots. In addition, the government's investments to support the companies as well as the indepth researches from the academic world should follow.

This research is significant in a way that the user perception of the home robot prices was investigated and suggested the directions and the criteria of the home robots. Moreover, this research can help set the appropriate prices of the home robots that the users may be willing to pay for and can contribute the consumption of the home robots through the reasonable price setting. Lastly, it is expected to be utilized to design and develop the home robots that the users can actually purchase. 


\section{Acknowledgments}

This work was supported by Industrial Technology Innovation Program (Design Technology Innovation Program) funded by the Ministry of Trade, Industry and Energy (MOTIE, Korea). (No. 10065470).

This paper is a revised and expanded version of a paper entitled "Service Classification of Home Robot" presented at The $14^{\text {th }} 2017$ International Interdisciplinary Workshop, Daejeon, Korea, (2017) December 21-23.

\section{References}

[1] The Korea Internet \& Security Agency, 2017, Power Review, KISA Report, 2107(1), (2017).

[2] Korea Evaluation Institute of Industrial Technology, Consumer Electronics Technology Trends at CES 2017, KEIT Report, 2017(1), (2017).

[3] H. K. Lee, "Competitiveness Evaluation and Policy Task of Robotics Industry", KERI Brief, vol. 17, no. 14, (2017).

[4] Y. Sim, "A Study on the Consumer's Perception and Behavior on Differentiations of the Price and the Quality of Transportation Fuels", Journal of Consumer Studies, vol. 13, no. 2, (2002).

[5] H. Y. Lee and S. H. Choi, "About Digital Home Platform and Service Robot", the Journal of Korea Robotics Society, vol. 3, no. 1, (2006).

[6] Y. G. Kim and K. D. Lee, "Ubiquitous Home Security Robot System based on Sensor Network", Journal of Korea robotics society, vol. 2, no. 1, (2007).

[7] W. Eom, Y. Kim, J. Lee, G. Choi and E. Sim, "Development Trend of Intelligent Robots", Current Industrical and Technological Trends in Aerospace, vol. 11, no. 1, (2013).

[8] J. H. Park and H. Y. Ryoo, "Service Classification of Home Robot", International Journal of Smart Home, vol. 11, no. 11, (2017), pp. 41-46.

[9] S. S. Nho, Y. J. Han and S. K. Yoo, "What is Like to Live as a Working-Mom in Korea", Korean Journal of Counseling and Psychotherapy, vol. 24, no. 2, (2012).

[10] J. Lee, H. Kim, H. Kim and H. Jo, "A Study on the Image of Working Moms found in Picture Books", Journal of Children's Literature and Education, vol. 18, no. 2, (2017).

[11] S. Yoo, Y. Lim and T. Kim, "The Effects of Mindfulness on a Working-Mom`s Cognitive and Psychological Flexibility”, Korea Journal of Counseling, vol. 18, no. 1, (2017). 